\title{
Molecular barcode and morphological analysis of Smilax purhampuy Ruiz, Ecuador
}

\author{
Pilar Soledispa ${ }^{1}$, Efrén Santos-Ordóñez ${ }^{\text {Corresp., } 2,3}{ }$, Migdalia Miranda ${ }^{4}$, Ricardo Pacheco ${ }^{2}$, Yamilet Irene Gutiérrez \\ Gaiten $^{5}$, Ramón Scull ${ }^{5}$ \\ 1 Facultad de Ciencias Químicas. Ciudadela Universitaria "Salvador Allende", Universidad de Guayaquil, Guayaquil, Ecuador \\ 2 Centro de Investigaciones Biotecnológicas del Ecuador, Campus Gustavo Galindo, Km. 30.5 vía Perimetral, P.0. Box 09-01-5863, ESPOL Polytechnic \\ University, Escuela Superior Politécnica del Litoral, ESPOL, Guayaquil, Ecuador \\ 3 Facultad de Ciencias de la Vida, Campus Gustavo Galindo, Km. 30.5 vía Perimetral, P.O. Box 09-01-5863, ESPOL Polytechnic University, Escuela Superior \\ Politécnica del Litoral, ESPOL, Guayaquil, Ecuador \\ 4 Facultad de Ciencias Naturales y Matemáticas, ESPOL Polytechnic University, Escuela Superior Politécnica del Litoral, ESPOL, Guayaquil, Ecuador \\ 5 Instituto de Farmacia y Alimentos, Universidad de La Habana, Ciudad Habana, Cuba \\ Corresponding Author: Efrén Santos-Ordóñez \\ Email address: gsantos@espol.edu.ec
}

Smilax plants are distributed in tropical, subtropical, and temperate regions in both hemispheres of the world. They are used extensively in traditional medicines in a number of countries. However, morphological and molecular barcodes analysis, which may assist in the taxonomic identification of species, are lacking in Ecuador. In order to evaluate the micromorphological characteristics of these plants, cross sections of Smilax purhampuy leaves were obtained manually. The rhizome powder, which is typically used in traditional medicines, was analyzed for micromorphological characteristics. All samples were clarified with $1 \%$ sodium hypochlorite. Tissues were colored with $1 \%$ safranin in water and were fixed with glycerinated gelatin. DNA was extracted from the leaves using a modified CTAB method for molecular barcode characterization and PCR was performed using primers to amplify the different loci including the plastid genome regions atpF-atpH spacer, matK gene, $r b c L$ gene, $r p o B$ gene, $r p o C 1$ gene, $p s b K-p s b l$ spacer, and trnH-psbA spacer; and the nuclear DNA sequence ITS2. A DNA sequence similarity search was performed using BLAST in the GenBank nr database and phylogenetic analysis was performed using the maximum likelihood method according to the best model identified by MEGAX using a bootstrap test with 1,000 replicates. Results showed that the micromorphological evaluation of a leaf cross section depicted a concave arrangement of the central vein, which was more pronounced in the lower section and had a slight protuberance. The micromorphological analysis of the rhizome powder allowed the visualization of a group of cells with variable sizes in the parenchyma and revealed thickened xylematic vessels associated with other elements of the vascular system. Specific amplicons were detected in DNA barcoding for all the barcodes tested except for the trnH-psbA spacer. BLAST analysis revealed that the 
Smilax species was predominant in all the samples for each barcode; therefore, the genus Smilax was confirmed through DNA barcode analysis. The barcode sequences $p s b K-p s b l$, atpF-atpH, and ITS2 had a better resolution at the species level in phylogenetic analysis than the other barcodes we tested. 
1 Molecular barcode and morphological analysis of

2 Smilax purhampuy Ruiz, Ecuador

3

4

\author{
Pilar Soledispa ${ }^{1}$, Efrén Santos-Ordóñez ${ }^{2,3}$, Migdalia Miranda4 ${ }^{4}$ Ricardo Pacheco², \\ Yamilet Irene Gutiérrez Gaiten ${ }^{5}$, Ramón Scull ${ }^{5}$ \\ ${ }^{1}$ Facultad de Ciencias Químicas. Ciudadela Universitaria "Salvador Allende", Universidad de \\ Guayaquil, Guayaquil, Ecuador
}

${ }^{2}$ Centro de Investigaciones Biotecnológicas del Ecuador, ESPOL Polytechnic University, Escuela Superior Politécnica del Litoral, ESPOL, Guayaquil, Ecuador

${ }^{3}$ Facultad de Ciencias de la Vida, ESPOL Polytechnic University, Escuela Superior Politécnica del Litoral, ESPOL, Guayaquil, Ecuador

${ }^{4}$ Facultad de Ciencias Naturales y Matemáticas, ESPOL Polytechnic University, Escuela Superior Politécnica del Litoral, ESPOL, Guayaquil, Ecuador

5Instituto de Farmacia y Alimentos, Universidad de La Habana, Ciudad Habana, Cuba

Corresponding Author:

Efrén Santos-Ordóñez

Km 30.5 vía Perimetral, Campus Gustavo Galindo, Guayaquil, 09-01-5863, Ecuador. Email address: gsantos@espol.edu.ec

\title{
Abstract
}

Smilax plants are distributed in tropical, subtropical, and temperate regions in both hemispheres of the world. They are used extensively in traditional medicines in a number of countries. However, morphological and molecular barcodes analysis, which may assist in the taxonomic identification of species, are lacking in Ecuador.

In order to evaluate the micromorphological characteristics of these plants, cross sections of Smilax purhampuy leaves were obtained manually. The rhizome powder, which is typically used in traditional medicines, was analyzed for micromorphological characteristics. All samples were clarified with $1 \%$ sodium hypochlorite. Tissues were colored with $1 \%$ safranin in water and were fixed with glycerinated gelatin. DNA was extracted from the leaves using a modified CTAB method for molecular barcode characterization and PCR was performed using primers to amplify the different loci including the plastid genome regions atp $F$ atpH spacer, matK gene, $r b c L$ gene, $r p o B$ gene, $r p o C 1$ gene, $p s b K-p s b /$ spacer, and $t r n H-p s b A$ spacer; and the nuclear DNA sequence ITS2. A DNA sequence 
similarity search was performed using BLAST in the GenBank nr database and phylogenetic analysis was performed using the maximum likelihood method according to the best model identified by MEGAX using a bootstrap test with 1,000 replicates. Results showed that the micromorphological evaluation of a leaf cross section depicted a concave arrangement of the central vein, which was more pronounced in the lower section and had a slight protuberance. The micromorphological analysis of the rhizome powder allowed the visualization of a group of cells with variable sizes in the parenchyma and revealed thickened xylematic vessels associated with other elements of the vascular system. Specific amplicons were detected in DNA barcoding for all the barcodes tested except for the $t r n H-p s b A$ spacer. BLAST analysis revealed that the Smilax species was predominant in all the samples for each barcode; therefore, the genus Smilax was confirmed through DNA barcode analysis. The barcode sequences $p s b K-p s b l$, atpF-atpH, and ITS2 had a better resolution at the species level in phylogenetic analysis than the other barcodes we tested.

\section{Introduction}

The genus Smilax (in the family Smilacaceae) consists of 310 species that are distributed in tropical, subtropical and temperate regions in both hemispheres of the world (Qi et al., 2013). According to Cameron et al. (2006), Smilacaceae are taxonomically confused and belong to the cosmopolitan family of Liliales. Due to morphological analysis, the division of Smilacaceae includes at least seven genera and five sections within the large genus Smilax. Plants are dioecious, vine, herbaceous, or rarely, sub-shrubs or shrubs. Leaves are simple, and alternating with petioles that have tendrils; the primary venation are acrodomous. Thicker stems are rippled while aerial stems are generally aculeate (Martins et al., 2013b). In Ecuador, the genus is not wellrecorded, although approximately ten species of this genus have been reported in the country according to Gaskin (1999).

Smilax is used a variety of ways in traditional medicine. For instance, in Brazil, Smilax longifolia Rich and Smilax syphilitica Humb \& Bonpl. ex Wild are used as diuretics and in the treatment of venereal diseases (Breitbach et al., 2013) and Smilax quinquenervia Vell is used as a tonic for rheumatism and as an anti-syphilitic (Andreata, 1997). In Central America, several species of Smilax are used as diuretics, and for dermatological infections, gastrointestinal disorders, rheumatism, vaginitis, contraception, menstrual regulation, anemia, snake bites, and arthritis. In Ecuador, Smilax species are used for the elimination of cholesterol and triglycerides, the treatment of arthritis, intestinal, stomach and prostate inflammations, chronic gastritis, and cysts (Ferrufino, 2004). Several pharmacological properties have been demonstrated, including glucoselowering (Romo-Pérez et al., 2019), anti-hyperuricemic (Huang et al., 2019), antiinflammatory and analgesic (Khana et al., 2019), diuretic (Pérez-Ramírez et al., 2016), and antioxidant (Fonseca et al., 2017) effects. Several chemical compounds have been identified in the genus, including polysaccharides (Zhang et al., 2019), steroidal saponins (Luo et al., 2018), and flavonoids (Wang et al., 2019), among others. 
82 Smilax purhampuy is native to the Amazon and is distributed throughout Ecuador, Peru,

83 Nicaragua, Colombia, Bolivia, Costa Rica, Venezuela, Honduras, and Brazil (Rivas et al.,

84 2017). S. purhampuy is traditionally known for its healing and therapeutic properties. It

85 has been used to treat cholesterol and triglycerides, chronic gastritis, cysts, arthritis, and

86 intestinal, stomach, and prostate inflammations (JR Global del Perú, 2011). However,

87 information on S. purhampuy is limited.

88 Morphological and molecular barcode analysis are lacking for S. purhampuy in Ecuador,

89 despite its medicinal use. Phylogenetic analysis of the Smilax genus includes

90 microsatellites (Martins et al., 2013a; Ru et al., 2017; Qi et al., 2017) which are also

91 informative tools for genetic diversity and gene flow studies. Other methods for the

92 phylogenetic analysis of plants includes DNA barcodes, which may be used as a

93 complementary tool in the taxonomic identification of the species; for instance, the

94 plastid genome regions atpF-

95 atpH spacer, matK gene, $r b c L$ gene, rpoB gene, rpoC1 gene, $p s b K-p s b /$ spacer, 96 and $t r n H-p s b A$ spacer have been tested as universal plant barcodes (CBOL Plant

97 Working Group, 2009). The chloroplast genes $r b c L$ and matK, are recommended to 98 characterize land plants as a 2-locus combination (CBOL Plant Working Group, 2009).

99 The first reported use of the DNA barcode in Smilax species included the rDNA ITS

100 sequence (Cameron et al., 2006) inferring phylogenetic relationships that elucidated the evolutionary and biogeographic history of the genera from the Smilacaceae family. Sulistyaningsih et al. (2018) used the DNA barcode $r b c L$ for phylogenetic analysis of Smilax spp. in Java, Indonesia. Qi et al. (2013) used the DNA barcodes ITS, matK and the $r p / 16$ intron in Smilacaceae indicating that the phylogenetic relationships largely contradicted the traditional morphological classification of the family. Wang et al. (2014) used the DNA barcode $p s b A$-trnH to distinguish Smilax glabra from its related species, and Kritpetcharat et al. (2011) used the trnH-psbA spacer barcode for Smilax china and $S$. glabra indicating that measuring the genetic distance may be used to discriminate between the two species. In a broader study which includes four species of Smilax and other trees, Liu et al. (2015) used the DNA barcodes $r b c L$, matK, ITS, ITS2, and $t r n H-$ $p s b A$ to analyze the diversity and species resolution, concluding that the combination of the loci rbcl+ITS2 is an effective tool for documenting plant diversity in the Dinghushan

113 National Nature Reserve in China. Other loci in medicinal plants have been proposed

114 for their characterization, including the nuclear sequence ITS2 (Zhang et al., 2016).

115 Furthermore, DNA barcodes could be used to distinguish adulterated drugs (Kumari et

116 al., 2016). Therefore, DNA barcode analysis should be performed for Smilax species to

117 verify the results of taxonomic and morphological studies. We investigated the

118 micromorphological and molecular barcode characterization of S. purhampuy Ruiz

119 collected in Ecuador and found that the barcodes psbK-psbl, atpF-atpH, and ITS2 could be used in Smilax plants for a better resolution at the species level.

\section{Materials and Methods}

The climea of

124

The climate of the study area is rainy megathermal with an average monthly temperature between $22^{\circ} \mathrm{C}$ and $26^{\circ} \mathrm{C}$ and average rainfall between 2,000 to $3,000 \mathrm{~mm}$ per year. The study area is a tropical humid forest. 
128 Collection of plant material

129 Plant material was collected from three specimens of S. purhampuy Ruiz in the

130 Francisco de Orellana Province in Ecuador (coordinates $1^{\circ} 10^{\prime} 03.7^{\prime \prime} S$ 76 $56^{\prime} 30.9^{\prime \prime} \mathrm{W}$ ) in

131 March and April of 2019. The samples were collected from shaded-exposed plants.

132 Branches containing leaves, fruits, and the rhizome were transferred to the GUAY

133 herbarium of the Faculty of Natural Sciences of the University of Guayaquil for

134 taxonomic characterization. Samples were identified as S. purhampuy Ruiz (voucher

135 number 13,117).

136

137

138

139

140

141

142

143

144

145

146

147

148

149

150

151

152

153

154

155

156

157

158

159

160

161

162

163

164

165

166

167

168

169

170

171

172

173

\section{Plant material preparation}

Leaves and rhizomes were washed with water. The leaves used in the micromorphological study were analyzed and stored at $-80^{\circ} \mathrm{C}$ for DNA extraction. The rhizomes were dried in a Mettler Toledo stove at $40^{\circ} \mathrm{C}$ and then samples of the rhizomes were crushed with a manual knife mill and stored in amber glass jars for analysis.

\section{Micromorphological analysis}

Leaf samples were taken from the middle of the lamina for the evaluation of their micromorphological characteristics. The mid-rib was cut transversely according to the manual method (Miranda and Cuéllar, 2000). The maximum sample width was $1 \mathrm{~cm}$ including the mid-rib. Transversal cuts of fresh leaves were hydrated and clarified with $1 \%$ sodium hypochlorite. Tissues were colored with $1 \%$ safranin in water and fixed with glycerinated gelatin according to the method by Gatusso and Gatusso (1999). The powder obtained from the rhizomes was hydrated, clarified with $1 \%$ sodium hypochlorite and colored with $1 \%$ safranin in water and fixed with glycerinated gelatin (Gattuso and Gattuso, 1999; Miranda and Cuellar, 2000). We performed a histochemical reaction with Lugol reagent to detect starch in the powdered drug obtained from the rhizomes (Gattuso and Gattuso, 1999). Morphological analysis was performed using a NOVEL light microscope at 10x magnification, attached to an HDCE-50B digital camera, model 146 HDCE-50B.

\section{DNA extraction and PCR}

Leaf samples from the three $S$. purhampuy Ruiz plants (with codes CIBE-010, CIBE011, CIBE-012) were ground with MM400 (Retsch, Haan, Germany) and liquid nitrogen and were stored at $-80^{\circ} \mathrm{C}$. DNA extraction was performed for each Smilax plant independently. A modified CTAB protocol was used for total DNA extraction according to Pacheco Coello et al. (2017). The master mix GoTaq ${ }^{\circledR} 2 x$ (Cat\# M7123, Promega) was used for PCR analysis according to the manufacturer's instructions using $0.5 \mu \mathrm{M}$ for each primer according to the barcode used (Table S1) in a $50 \mu \mathrm{L} \mathrm{PCR} \mathrm{reaction.} \mathrm{The}$ conditions for the PCR were: $95^{\circ} \mathrm{C}$ for 3 min for initial denaturation; 35 cycles of $95^{\circ} \mathrm{C}$ for $30 \mathrm{~s}, 50^{\circ} \mathrm{C} / 56^{\circ} \mathrm{C} / 60^{\circ} \mathrm{C}$ (depending of the barcode, Table S1) for $60 \mathrm{~s}, 72^{\circ} \mathrm{C}$ for $60 \mathrm{~s}$; and a final extension of $72^{\circ} \mathrm{C}$ for $10 \mathrm{~min}$. Amplicons were detected by sampling $5 \mu \mathrm{L}$ in agarose gel $(1.5 \%)$ electrophoresis. The remaining $45 \mu \mathrm{L}$ was purified and sequenced commercially (Macrogen, Rockville, MD, USA). At least two technical replicates were sequenced and a consensus was generated for each biological replicate. 
174 Bioinformatic analysis

175 Sequences were processed using MEGAX (Stecher et al., 2020). Technical replicates

176 were aligned with MUSCLE and a consensus sequence was generated for each

177 barcode. Consensus sequences were analyzed by BLAST (Zhang et al., 2000) in the

178 GenBank non-redundant nucleotide database (nr). The $\mathrm{nr}$ database included the

179 accessions of the complete plastid genomes of Smilax spp. representing three species

180 and also accessions containing sequences of single locus, indicating that the results

181 were dependent on the sequence availability in the database at the time of the analysis

182 (28 $8^{\text {th }}$ June 2020). Accessions were selected for phylogenetic analysis based on BLAST

183 analysis. For each barcode, the accessions and samples sequences were aligned using

184 MUSCLE and the recommended model from MEGAX was used. The aligned

185 sequences were trimmed at the ends to allow for all sequences to maintain the same

186 range. The maximum likelihood method was performed according to the best model

187 found by MEGAX using bootstrap test (1,000 replicates).

\section{Results}

\section{Morphological analysis}

The micromorphological evaluation of a cross section of the leaf sample (Fig. 1A)

193 showed a concave arrangement of the central midrib, which was more pronounced in the lower part with a slight protuberance. The mesophyll showed a well-defined adaxial and abaxial uniseriate epidermis with a fine cuticle on the lateral sides of the central vein. Below the adaxial epidermis, we observed a palisade parenchyma forming two or three continuous layers of elongated cells. The spongy parenchyma exhibited cells of variable size that bordered the abaxial epidermis. An enlargement of the central vein (Fig. 1B) showed the fundamental parenchyma, which was formed by many isometric cells. The sclerenchyma tissue was characterized by lignified thickened walled cells surrounding a well-defined vascular system (xylem and phloem) near the middle of the central vein, which harbored six vascular bundles of variable size.

Micromorphological analysis of the drug obtained from the rhizome (Fig. 2) allowed the visualization of a group of cells of the parenchyma of variable size (Fig. 2A) and revealed thickened xylematic vessels associated with other elements of the vascular system (Fig. 2B). Elongated, fusiform, and pointed structures were also visualized, which corresponded to fibers and may suggest a type of filiform sclerides (Fig. 2C). We observed xylematic thickening vessels with holes in another sample of the powder drug (Fig. 2D). Numerous starch granules of variable size were observed showing a blackish coloration with the Lugol reagent (Fig. 2E).

\section{Molecular barcodes for Smilax purhampuy Ruiz plants}

Specific PCR amplification was detected for all barcodes except for trnH-psbA (data not shown). BLAST analysis was performed for each barcode sequence (Data S1, Data S2) and the best hit for all samples for each barcode indicated the Smilax species (Table 1). BLAST analysis indicated the presence of Smilax spp. using the sequences available at the $\mathrm{nr}$ database, including plastid genomes and single locus sequence. The best hits in BLASTn for the different species included: S. nipponica for $p s b K-p s b l(96.57 \%, 96.56 \%$, and $93.83 \%$ of identity for the three biological replicates, respectively); S. nipponica and S. china for $r p o B(99.73 \%$ for the three biological replicates); S. nipponica, S. china, and 
220 S. aspera for $r p o C 1$ (100\%); S. sieboldii f. inermis for atpF-atpH $(90.66 \%, 90.69 \%$, and

221

222

223

224

225

226

227

228

229

230

231

232

233

234

235

236

237

238

239

240

241

242

243

244

245

246

247

248

249

250

251

252

253

254

255

256

257

258

259

260

261

262

263

264

265 $96.47 \%)$, S. fluminensis $(99.65 \%, 100 \%)$, S. bona-nox $(99.88 \%)$ and S. laurifolia $(99.88 \%)$ for matK; S. aspera $(99.82 \%, 99.82 \%)$ and S. laurifolia $(99.82 \%)$ for $r b c L$; and S. excelsa $(80.49 \%, 80.05 \%$ ) for ITS2 (only two biological replicates were sequenced successfully for ITS2).

We determined the best models for phylogenetic analysis were: $T 92+G+I(r b c L), T 92+G$ (matK, ITS2, psbK-psbl, atpF-atpH), T92 (rpoB), and JC (rpoC1) after alignment of the barcode sequences between the $S$. purhampuy from this study and different accessions including other genera. Phylogenetic analysis revealed that for $p s b K-p s b l$, the $S$. purhampuy sequences shared a clade (99 bootstrap) with different Smilax species, including S. china, S. nipponica, and S. glycophylla; and with two accessions from another genus, including Hemidesmus indicus (Fig. 3). However, the S. purhampuy sequences CIBE-010 and CIBE-011 are grouped in a subclade (bootstrap 96), while $S$. purhampuy CIBE-012 shared a clade with both S. purhampuy (bootstrap 30). The other major clades in the phylogenetic tree corresponded to other genera. For the $r p o B$ the phylogenetic tree revealed that the $S$. purhampuy samples were in a clade (98 bootstrap) with other Smilax species; while other genera including Brahea spp., Philesia magellanica, Tricyrtis macropoda, Fritillaria spp., and Lilium spp. were in other clades (Fig. S1). The S. purhampuy samples for the rpoC1 were in a clade with different species of Smilax, including S. aspera (accession number EU531650), S. nipponica (MT261170), S. china (MT261168), and S. herbacea (HQ594138, HQ594139, Fig. S1). The atpF-atpH phylogenetic analysis revealed that several Smilax species were in the same clade. However, the S. purhampuy samples from this study are in a subclade (bootstrap 99). For the matK and $r b c L$ barcodes, the same pattern was observed where a clade sharing different Smilax species was encountered (Fig. S1), although a subclade was formed with the two $S$. purhampuy samples (CIBE-010, CIBE-011) and S. fluminensis; while for the $S$. purhampuy CIBE-012 sample, a branch was shared with $S$. aspera for matK. Furthermore, in the $r b c L$ phylogenetic tree, a subclade was formed for S. purhampuy samples CIBE-010 and CIBE-011 with other species including $S$. aspera, while for the $S$. purhampuy CIBE-012 a clade was shared with $S$. domingensis and $S$. lauriflora. The ITS2 phylogenetic tree (Fig. 4) revealed that the two S. purhampuy samples (CIBE-010 and CIBE-011) were in a different clade (bootstrap 99) apart from the other Smilax species, including $S$. aspera, S. stans, S. menispermoidea, $S$. trachypoda, S. aberrans, S. retroflexa, S. excelsa, S. lunglingensis, S. hispida, S. japonica, S. china, and S. pumila.

\section{Discussion}

\section{Microscopic analysis}

We made a detailed assessment of the herbal drugs and used microscopy to identify them based on their known histological characteristics (Shailesh et al., 2015).

Micromorphological studies are essential for the quality control of plant-derived drugs, since significant details are used to correctly identify the plant and possible adulterants. The cross section of the $S$. purhampuy leaf indicated that the abaxial and adaxial epidermis are uniseriate, with the existence of an easily perceptible cuticle. Morphoanatomic studies performed on the leaves of various Smilax species ( $S$.

Peer) reviewing PDF | (2020:08:51616:3:0:NEW 29 Jan 2021) 
266 brasiliensis, S. campestris, S. cisoides, S. fluminensis, S. goyazana, S. oblongifolia, and

267 S. rufescens) revealed a non-stratified epidermis with thick cuticle (Martins et al.,

268 2013b). These results correspond to those of previous studies and may be a distinctive

269 anatomical characteristic of the genus.

270 In most plants, the leaf mesophyll harbors palisade and spongy tissue, which differ in

271 location, cell morphology, and function. In plants with a dorsiventral mesophyll, the

272 palisade tissue is located on the adaxial side and the spongy tissue on the abaxial side;

273 this distribution makes a greater contribution to the photosynthesis process (Yahia et

274 al., 2019). Studies by various researchers have shown that the mesophyll could vary

275 from one leaf to another of the same individual or of different individuals, depending on

276 light intensity and salt concentration (Gapińska and Glińska, 2014). In S. purhampuy a

277 dorsiventral mesophyll was observed where the palisade parenchyma is toward the

278 adaxial side and the spongy parenchyma was located toward the abaxial side, which

279 supports the results of Martins and Appezzato-da-Glória (2006) for S. polyantha and

280 Martins et al. (2013b) for S. brasiliensis, S. campestris, S. cissoids, S. goyazana, S.

281 oblongifolia and S. rufescens. The presence of six vascular bundles of variable size at

282 the level of the central vein of the leaf was unique and differed from other Smilax

283 species (S. brasiliensis, S. cissoides, and S. fluminensis), which present three vascular

284 bundles (Martins et al., 2013b).

285 The presence of parenchyma tissue, xylematic vessels, fibers and starch granules are

286 reported in S. domingensis from Cuba and Guatemala (Cáceres et al., 2012; González

287 et al., 2017), which was support by the present study. The difference lies within the

288 morphology and arrangement of these structures. For example, thickened scalariformly

289 xilematic vessels and fibrotraqueids (fibers) were detected in S. domingensis, while

290 thickened xilematic vessel with holes and filiform sclerides (fibers) were observed in the

291 studied species.

292

293

294

295

296

297

298

299

300

301

302

303

304

305

306

307

308

309

310 Group, 2009). Generally, the BLASTn analysis relies in the presence of those species in

311 the GenBank for species identification; consequently, the results presented in the

Peer] reviewing PDF | (2020:08:51616:3:0:NEW 29 Jan 2021) 
312 BLAST analysis and in the phylogenetic trees depended on the sequences available in

313 the nr database in the GenBank. Therefore, a complete analysis using different species

314 of Smilax should be performed in the future for all the DNA barcodes tested.

315 We analyzed the three samples taxonomically identified as S. purhampuy Ruiz (CIBE-

316 010, CIBE-011, CIBE-012) which were more similar than other Smilax species,

317 including S. nipponica, S. glycophylla, S. herbacea, S. china, S. sieboldin, S. aspera, S.

318 stans, S. menispermoidea, S. trachypoda, S. aberrans, and S. pumila. These results

319 were also observed in the phylogenetic trees for $p s b K-p s b /$ spacer, atpF-atpH spacer,

320 and ITS2. However, few accessions were encountered in the GenBank for the DNA

321

322

323

324

325

326

327

328

329 barcodes $p s b K-p s b /$ spacer and atpF-atpH spacer. There should be additional study of the different Smilax species for these barcodes, however, other DNA barcodes may accurately identify the genus level. The ITS2 revealed a low percentage of identification $(80.49 \%)$ with BLASTn, suggesting that species differentiation could be detected using the ITS2. The results from other studies have indicated a better resolution for species identification using the ITS2 in medicinal plants (Techen et al., 2014; Zhang et al., 2016; Bustamante et al., 2019; Sarmiento et al., 2020).

Our results determined that the rpoC1 sequence was not accurate at the species level, and that matK could not be used to discriminate between S. purhampuy and $S$.

330

331 fluminensis. Furthermore, the $r b c L$ barcode could not be used for species differentiation in the Smilax genus, as a low bootstrap value was observed in the different clades formed. The $p s b K-p s b l$, atpF-atpH, and ITS2 had a better resolution at the species level for $S$. purhampuy. Future research should include the sequencing of selected barcodes ( $r b c L$, matK, psbK-psb/ spacer, atpF-atpH spacer, and ITS2) for different species of the Smilax genus found in Ecuador with biological replicates. Further studies should establish a reliable DNA barcode analysis and test different 2-locus combinations to determine which barcode should be used for species identification in the Smilax genus.

\section{Conclusions}

340

We determined the morphological characteristics and conducted molecular barcode

341

342 analysis on S. purhampuy Ruiz plants collected in Ecuador. The micromorphological characteristics of the leaves and rhizomes were described for the first time, which constitutes a novel contribution to the botanical characterization of the species. The taxonomic classification of Smilax was confirmed by the molecular barcodes used, including $p s b K-p s b l, r p o B, r p o C$, atpF-atpH, matK, rbcL, and ITS2. Furthermore, the barcodes sequences $p s b K-p s b l$, atp $F-a t p H$, and ITS2 indicated a better resolution at the species level than the other barcodes tested in this study. These barcodes ( $p s b K-p s b l$, atpF-atpH, and ITS2) could be used to identify other species in the genus Smilax. However, further molecular barcode analysis should be performed on Smilax spp. from Ecuador to determine its diversity and to complete its taxonomic classification. Furthermore, the medicinal properties of the Smilax plants used in this study should be studied in greater detail. 
356 Identification of samples by the GUAY herbarium of the Faculty of Natural Sciences of 357 the Guayaquil University is acknowledged.

\section{References}

361 Andreata RHP. 1997. Revisão das espécies brasileiras do gênero Smilax Linnaeus (Smilacaceae).

Basak S, Aadi Moolam R, Parida A, Mitra S, Rangan L. 2019. Evaluation of rapid molecular diagnostics for differentiating medicinal Kaempferia species from its adulterants. Plant Diversity 41(3):206-211

Bustamante K, Santos-Ordóñez E, Miranda M, Pacheco R, Gutiérrez Y, Scull R. 2019. Morphological and molecular barcode analysis of the medicinal tree Mimusops coriacea (A.DC.) Miq. collected in Ecuador. PeerJ 7:e7789

Cáceres A, Cruz SM, Martínez V, Gaitán I, Santizo A, Gattuso S, Gattuso M. 2012. Ethnobotanical, pharmacognostical, pharmacological and phytochemical studies on Smilax domingensis in Guatemala. Brazilian Journal of Pharmacognosy 22(2):239-248

Cameron KM, Fu C. 2006. A nuclear rDNA phylogeny of Smilax (Smilacaceae). Aliso 22:598-605

CBOL Plant Working Group. 2009. A DNA barcode for land plants. Proceedings of the National Academy of Sciences of the United States of America 106(31):12794-12797

Costion C, Ford A, Cross H, Crayn D, Harrington M, Lowe A. 2011. Plant DNA barcodes can accurately estimate species richness in poorly known floras. PLoS One 6(11):e26841

Cheng T, Xu C, Lei L, Li C, Zhang Y, Zhou S. 2015. Barcoding the kingdom Plantae: new PCR primers for ITS regions of plants with improved universality and specificity. Molecular Ecology Resources 16(1):138-149

Ferrufino L, Gómez J. 2004. Estudio morfológico de Smilax L. (Smilacaceae) en Costa Rica, con implicaciones sistemáticas. Lankesteriana 4(1):5-36

Fonseca JC, Barbosa MA, Silva ICA, Duarte-Almeida JM, Castro AHF, dos Santos Lima LAR. 2017. Antioxidant and allelopathic activities of Smilax brasiliensis Sprengel (Smilacaceae). South African Journal of Botany 111:336-340

Gapińska M, Glińska S. 2014. Salt-mediated changes in leaf mesophyll cells of Lycopersicon esculentum Mill. plants. Journal of Central European Agriculture 15(3):219-235

Gaskin J. 1999. Smilacaceae. In: P.M. Jørgensen \& S. León-Yánez (eds.). Catalogue of the vascular plants of Ecuador. Monogr. Syst. Bot. Missouri Bot. Gard. 75

Gattuso MA, Gattuso SJ. 1999. Manual de procedimientos para el análisis de drogas en polvo. Rosario: Editorial de la Universidad Nacional de Rosario Urquiza.

González YJ, Monan M, Cuéllar A, de Armas T, Gómez E, Dopico E. 2017. Pharmacognostic and Phytochemical Studies of Smilax domingensis Willd. in Cuba. American Journal of Plant Sciences 8:1462-1470 
407 Huang L, Deng J, Yuan C, Zhou M, Liang J, Yan B, Shu J, Liang Y, Huang H. 2019. The anti-

408 hyperuricemic effect of four astilbin stereoisomers in Smilax glabra on hyperuricemic mice. Journal of

409 Ethnopharmacology 238:111777

410

411

412

413

414

415

416

417

418

419

420

421

422

423

424

425

426

427

428

429

430

431

432

433

434

435

436

437

438

439

440

441

442

443

444

445

446

447

448

449

450

451

452

453

454

455

456

457

458

459

460

JR Global del Perú S.A.C. INKAPLUS. Ficha Técnica-Zarzaparrilla. [Online].; 2011 [cited 20190708.

Available from: http://www.inkaplus.com/media/web/pdf/Zarzaparrilla.pdf.

Khana AK, Singha PD, Reeseb PB, Howdena J, Thomasa TT. 2019. Investigation of the anti-

inflammatory and the analgesic effects of the extracts from Smilax ornata Lem. (Jamaican sarsaparilla)

plant. Journal of Ethnopharmacology 240:111830

Kritpetcharat O, Khemtonglang N, Kritpetcharat P, Daduang J, Daduang S, Suwanrungruang K, Bletter N, Sudmoon R, Chaveerach A. 2011. Using DNA markers and barcoding to solve the common problem of identifying dried medicinal plants with the examples of Smilax and Cissus in Thailand. Journal of Medicinal Plants Research 5(15):3480-3487

Kumar S., Stecher G., Li M., Knyaz C., and Tamura K. 2018. MEGA X: Molecular Evolutionary Genetics Analysis across computing platforms. Molecular Biology and Evolution 35:1547-1549.

Kumari R, Kotecha M. A review on the Standardization of herbal medicines. 2016. International Journal of Pharma Sciences and Research 7(2):97-106

Liu J, Yan H-F, Newmaster SG, Pei N, Ragupathy S, Ge X-J. 2015. The use of DNA barcoding as a tool for the conservation biogeography of subtropical forests in China. Diversity and Distributions 21(2):188199.

Luo R, Gao XL, Shi Cha, Wei YX, Hou PY, Li HG, Wang SQ, Anderson S, Zhang YW, Wu XH. 2018. Phytochemical and chemotaxonomic study on the rhizomes of Smilax riparia (Liliaceae). Biochemical Systematics and Ecology 76:58-60

Martins AR, Bombo AB, Soares AN, Appezzato-da-Glória B. 2013b. Aerial stem and leaf morphoanatomy of some species of Smilax. Brazilian Journal of Pharmacognosy 23(4):576-584

Martins AR, Abreu AG, Bajay MM, Villela PM, Batista CE, Monteiro M, Alves-Pereira A, Figueira GM, Pinheiro JB, Appezzato-da-Glória B, Zucchi MI. 2013a. Development and characterization of microsatellite markers for the medicinal plant Smilax brasiliensis (Smilacaceae) and related species. Applications in Plant Science 1(6):apps.1200507

Martins AR, Appezzato-da-Glória B. 2006. Morfoanatomia dos órgãos vegetativos de Smilax polyantha Griseb. (Smilacaceae). Brazilian Journal of Botany 29:555-567

Miranda MM, Cuéllar AC. 2000. Manual de prácticas de laboratorio. Farmacognosia y productos naturales. Ciudad Habana. 25-49, 74-79

Shailesh LP, Suryawanshi AB, Gaikwad MS, Pedewad SR, Potulwar AP. 2015. Standardization of herbal drugs: An overview. The Pharma Innovation Journal 4(9):100-104

Pacheco Coello R, Pestana Justo J, Factos Mendoza A, Santos Ordoñez E. 2017. Comparison of three DNA extraction methods for the detection and quantification of GMO in Ecuadorian manufactured food. BMC Research Notes 10(1):758

Pérez-Ramírez IF, Enciso-Moreno JA, Guevara-González RG, Gallegos-Corona MA, Loarca-Piña G, Reynoso-Camacho R. 2016. Modulation of renal dysfunction by Smilax cordifolia and Eryngium carlinae, and their effect. on kidney proteome in obese rats. Journal of Functional Foods 20:545-555 
462 Qi Z, Cameron KM, Li P, Zhao Y, Chen S, Chen G, Fu C. 2013. Phylogenetics, character evolution, and 463 distribution patterns of the greenbriers, Smilacaceae (Liliales), a near-cosmopolitan family of monocots.

464

465

466

467

468

469

470

471

472

473

474

475

476

477

478

479

480

481

482

483

484

485

486

487

488

489

490

491

492

493

494

495

496

497

498

499

500

501

502

503

504

505

506

507

508

509

510

511

512

513

514

515

Botanical Journal of the Linnean Society 173:535-548

Qi ZC, Shen C, Han YW, Shen W, Yang M, Liu J, Liang ZS, Li P, Fu CX. 2017. Development of microsatellite loci in Mediterranean sarsaparilla (Smilax aspera; Smilacaceae) using transcriptome data. Applications in Plant Sciences. 5(4):apps.1700005.

Rivas MdPP, Muñoz DGL, Ruiz MAC, Fernández LFT, Muñoz FAC, Pérez NM. Global Biodiversity Information Facility (GBIF). [Online].; 2017 [cited 201908 05. Available from: https://www.gbif.org/species/5295631.

Romo-Pérez A, Escandón-Rivera SM, Andrade-Cetto A. 2019. Chronic hypoglycemic effect and phytochemical composition of Smilax moranensis roots. Revista Brasileira de Farmacognosia 29(2):246253

Ru Y, Cheng R, Shang J, Zhao Y, Li P, Fu C. 2017. Isolation and characterization of microsatellite loci for Smilax sieboldii (Smilacaceae). Applications in Plant Sciences 5(3):apps.1700001.

Sarmiento-Tomalá G, Santos-Ordóñez E, Miranda-Martínez M, Pacheco-Coello R, Scull-Lizama R, Gutiérrez-Gaitén Y, Delgado-Hernández R. 2020. Short Communication: Molecular barcode and morphology analysis of Malva pseudolavatera Webb \& Berthel and Malva sylvestris $L$ from Ecuador. Biodiversitas 21(8):3554-3561

Sulistyaningsih LD, Abinawanto, Ardiyani M, Salamah A. 2018. Short Communication: Phylogenetic analysis and molecular identification of Canar (Smilax spp.) in Java, Indonesia Based on DNA Barcoding Analysis. Biodiversitas 19(2):364-368.

Stecher G, Tamura K, Kumar S. 2020. Molecular Evolutionary Genetics Analysis (MEGA) for macOS. Molecular Biology and Evolution 37(4):1237-1239

Techen N, Parveen I, Pan Z, Khan IA. 2014. DNA barcoding of medicinal plant material for identification. Current Opinion in Biotechnology 25:103-110

Wang S, Fanga Y, Yud X, Guoa L, Zhanga X, Xiaa D. 2019. The flavonoid-rich fraction from rhizomes of Smilax glabra Roxb. ameliorates renal oxidative stress and inflammation in uric acid nephropathy rats through promoting uric acid excretion. Biomedicine \& Pharmacotherapy 111:162-168

Wang ZT, Hao H, Lin LZ, Yu Y, Li SY. 2014. [Identification of Smilax glabra and its related species based on psbA-trnH sequence]. Zhong Yao Cai 37(8):1368-71

Yahia EM, López AC, Malda BG, Suzán AH, Queijeiro BM. 2019. Chapter 3 - Photosynthesis. In: Postharvest Physiology and Biochemistry of Fruits and Vegetables 47-72

Zhang D, Jiang B, Duan L, Zhou N. 2016. Internal transcribed spacer (ITS), an ideal DNA barcode for species discrimination in Crawfurdia Wall. (Gentianaceae) African Journal of Traditional, Complementary and Alternative Medicines 13(6):101-106

Zhang Y, Pan X, Ran S. 2019. Purification, structural elucidation and anti-inflammatory activity in vitro of polysaccharides from Smilax china L. International Journal of Biological Macromolecules 139:233-243

Zhang Z, Schwartz S, Wagner L, Miller W. 2000. A greedy algorithm for aligning DNA sequences. Journal of Computational Biology 7(1-2):203-214

Peer] reviewing PDF | (2020:08:51616:3:0:NEW 29 Jan 2021) 
517

518

Peer) reviewing PDF | (2020:08:51616:3:0:NEW 29 Jan 2021) 


\section{Table 1 (on next page)}

Blastn analysis for seven different barcodes of Smilax purhampuy Ruiz plants (CIBE-010, CIBE-011, CIBE-012). Results were ranked for the first three with the highest percentage of identity. Species with the best results are bold for each barcode. 
1 Table 1. Blastn analysis for seven different barcodes of Smilax purhampuy Ruiz plants (CIBE-010, CIBE-011, CIBE-012). Results

2 were ranked for the first three with the highest percentage of identity. Species with the best results are bold for each barcode.

\begin{tabular}{|c|c|c|c|c|c|c|c|c|c|c|}
\hline \multirow[b]{3}{*}{ Barcode } & \multirow[b]{3}{*}{ code } & \multicolumn{9}{|c|}{ Blastn rank } \\
\hline & & & & & & 2 & & & 3 & \\
\hline & & Organism & Accesion & $\begin{array}{l}\% \\
\text { identity }\end{array}$ & Organism & Accesion & $\begin{array}{l}\% \\
\text { identity }\end{array}$ & Organism & Accesion & $\begin{array}{l}\% \\
\text { identity }\end{array}$ \\
\hline \multirow[t]{3}{*}{$p s b K-p s b I$} & CIBE-010 & Smilax nipponica & MT261170.1 & $96.57 \%$ & Smilax china & MT261168.1 & $95.91 \%$ & Smilax glycophylla & $\underline{\text { MT261169.1* }}$ & $92.69 \%$ \\
\hline & CIBE-011 & Smilax nipponica & $\begin{array}{l}* \\
\text { MT261170.1 }\end{array}$ & $96.56 \%$ & Smilax china & $\begin{array}{l}* \\
\text { MT261168.1 }\end{array}$ & $95.91 \%$ & Smilax glycophylla & MT261169.1* & $92.67 \%$ \\
\hline & CIBE-012 & Smilax nipponica & * & $93.83 \%$ & Smilax china & & $93.20 \%$ & Smilax glycophylla & MT261169.1* & $89.32 \%$ \\
\hline \multirow[t]{3}{*}{ rров } & CIBE-010 & Smilax nipponica & $\frac{\text { MT261170.1 }}{\text { MT261170.1 }}$ & $99.73 \%$ & $\begin{array}{l}\text { Smilax } \\
\text { glycophylla } \\
\text { Smilax }\end{array}$ & $\frac{\text { MT261169.1 }}{\frac{*}{\text { MT261169.1 }}}$ & $99.73 \%$ & Smilax china & $\underline{\text { MT261168.1* }}$ & $99.47 \%$ \\
\hline & CIBE-011 & Smilax nipponica & $\frac{*}{\mathrm{MT} 261170.1}$ & $99.73 \%$ & $\begin{array}{l}\text { glycophylla } \\
\text { Smilax }\end{array}$ & $\begin{array}{l}* \\
\text { MT261169.1 }\end{array}$ & $99.73 \%$ & Smilax china & $\underline{\text { MT261168.1* }}$ & $99.46 \%$ \\
\hline & CIBE-012 & Smilax nipponica & (*....... & $99.73 \%$ & glycophyylla & * & $99.73 \%$ & Smilax china & MT261168.1* & $99.46 \%$ \\
\hline \multirow[t]{3}{*}{ rpoCl } & CIBE-010 & Smilax nipponica & $\begin{array}{l}\text { MT261170.1 } \\
\frac{*}{\text { MT261170.1 }} \\
\end{array}$ & $100.00 \%$ & Smilax china & $\begin{array}{l}\text { MT261168.1 } \\
\text { * } \\
\text { MT261168.1 }\end{array}$ & $100.00 \%$ & Smilax aspera & EU531650.1 & $100.00 \%$ \\
\hline & CIBE-011 & Smilax nipponica & $\begin{array}{l}* \\
\text { MT261170.1 }\end{array}$ & $100.00 \%$ & Smilax china & $\begin{array}{l}* \\
\text { MT261168.1 }\end{array}$ & $100.00 \%$ & Smilax aspera & EU531650.1 & $100.00 \%$ \\
\hline & CIBE-012 & Smilax nipponica & & $100.00 \%$ & Smilax china & & $100.00 \%$ & Smilax aspera & EU531650.1 & $100.00 \%$ \\
\hline \multirow[t]{3}{*}{ atpF-atpH } & CIBE-010 & $\begin{array}{l}\text { Smilax sieboldii f. } \\
\text { inermis } \\
\text { Smilax sieboldii f. }\end{array}$ & $\underline{\mathrm{JN} 417282.1}$ & $90.66 \%$ & Smilax sieboldii & $\underline{\mathrm{JN} 417281.1}$ & $90.64 \%$ & Hemidesmus indicus & $\underline{\text { NC } 047471.1}$ & $89.84 \%$ \\
\hline & CIBE-011 & $\begin{array}{l}\text { inermis } \\
\text { Smilax sieboldii f. }\end{array}$ & $\underline{\mathrm{JN} 417282.1}$ & $90.69 \%$ & Smilax sieboldii & $\underline{\mathrm{JN} 417281.1}$ & $90.68 \%$ & Smilax glycophylla & MT261169.1* & $89.03 \%$ \\
\hline & CIBE-012 & inermis & JN417282.1 & $96.47 \%$ & Smilax sieboldii & $J \mathrm{~N} 417281.1$ & $96.31 \%$ & Smilax china & MT261168.1* & $94.69 \%$ \\
\hline \multirow[t]{3}{*}{ matK } & CIBE- 010 & Smilax fluminensis & $\underline{\mathrm{JF} 461414.1}$ & $99.65 \%$ & Smilax coriacea & $\underline{\text { KJ719950.1 }}$ & $98.72 \%$ & Smilax havanensis & $\underline{\text { KF782873.1 }}$ & $98.72 \%$ \\
\hline & CIBE-011 & Smilax fluminensis & $\underline{\mathrm{JF} 461414.1}$ & $100.00 \%$ & Smilax coriacea & $\underline{\text { KJ719950.1 }}$ & $99.05 \%$ & Smilax havanensis & $\underline{\text { KF782873.1 }}$ & $99.05 \%$ \\
\hline & CIBE-012 & Smilax bona-nox & KC511353.1. & $99.88 \%$ & Smilax laurifolia & JF461393.1. & $99.88 \%$ & Smilax ligneoriparia & KX432989.1. & $99.76 \%$ \\
\hline \multirow[t]{3}{*}{$r b c L$} & CIBE- 010 & Smilax aspera & $\underline{\mathrm{KX} 394660.1}$ & $99.82 \%$ & Smilax aspera & $\underline{\mathrm{KX} 394659.1}$ & $99.82 \%$ & Smilax aspera & $\underline{\text { KM609079.1 }}$ & $99.82 \%$ \\
\hline & CIBE-011 & Smilax aspera & $\underline{\text { KX394660.1 }}$ & $99.82 \%$ & Smilax aspera & KX394659.1 & $99.82 \%$ & Smilax aspera & $\underline{\text { KM609079.1 }}$ & $99.82 \%$ \\
\hline & CIBE-012 & Smilax laurifolia & JF944386.1 & $99.82 \%$ & Smilax china & $\begin{array}{l}\frac{M 1}{*} \\
*\end{array}$ & $99.45 \%$ & Smilax gaudichaudiana & KX394669.1 & $99.45 \%$ \\
\hline \multirow[t]{2}{*}{ ITS2 } & CIBE-010 & Smilax excelsa & $\underline{\mathrm{JF} 461354.1}$ & $80.49 \%$ & Smilax aspera & $\underline{\text { KJ719926.1 }}$ & $80.24 \%$ & Smilax aspera & $\underline{\text { KJ719924.1 }}$ & $80.24 \%$ \\
\hline & CIBE-011 & Smilax excelsa & JF461354.1 & $80.05 \%$ & Smilax aspera & KJ719926.1 & $79.81 \%$ & Smilax aspera & $\underline{\text { KJ719924.1 }}$ & $79.81 \%$ \\
\hline
\end{tabular}


Figure 1

Microscopic characteristics of the leaf from Smilax purhampuy Ruiz

Transversal section of the central vein of the leaf $(A, B)$. AbE, abaxial epidermis; $A d E$, adaxial epidermis; FP, fundamental parenchyma; Me, mesophyll; PP, palisade parenchyma; SP, spongy parenchyma; ST, sclerenchyma tissue; Vs, vascular system
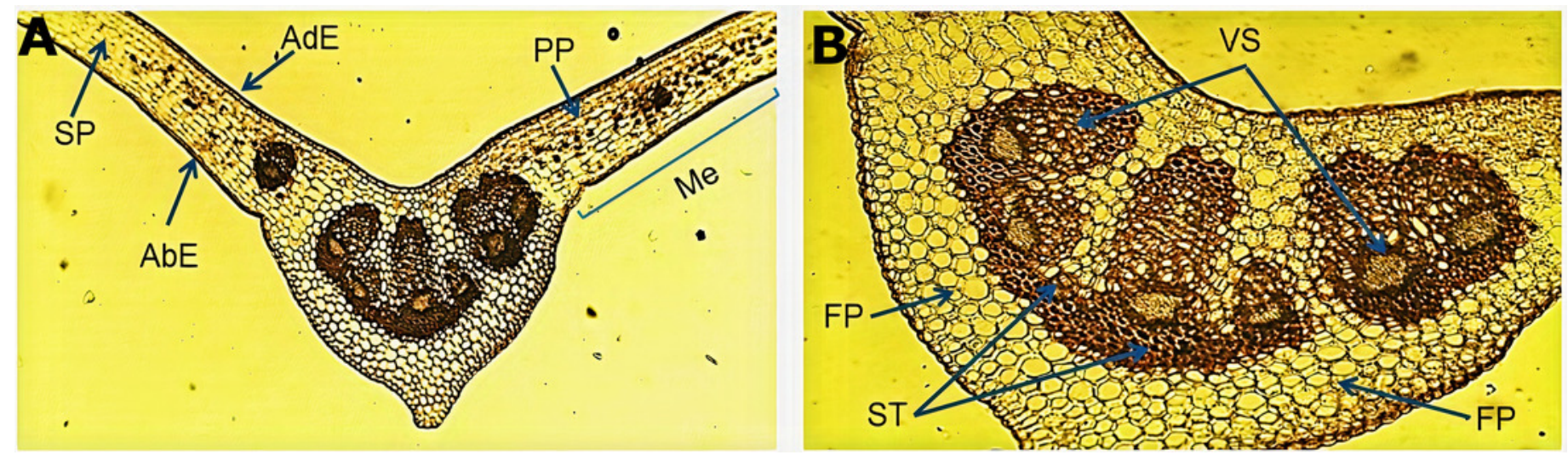
Figure 2

Microscopic characteristics of the powder drug from Smilax purhampuy Ruiz rhizome

A: parenchyma cells. B: xylematic veseels and other elements of the vascular system. C: fibers (filiform sclerides). D: xylematic veseels, E: starch granules
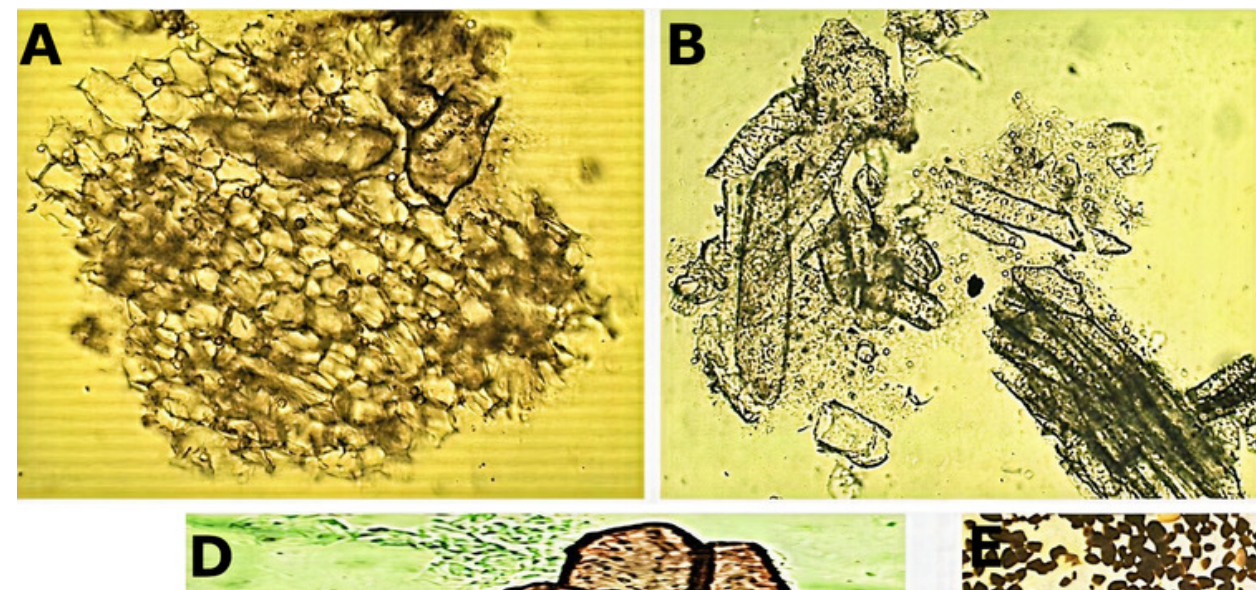

D

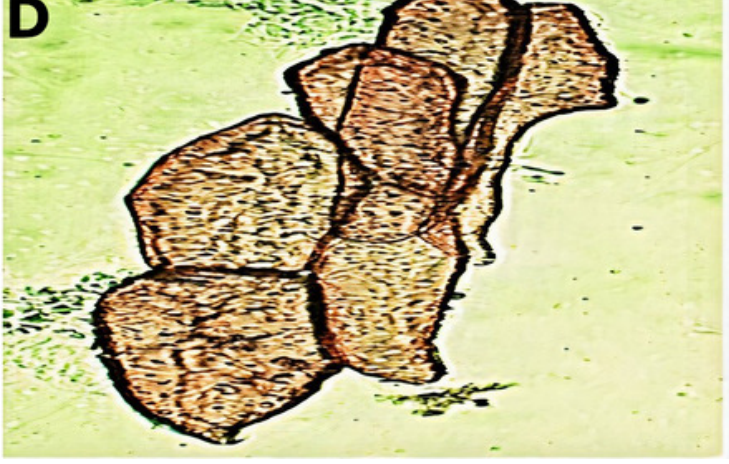

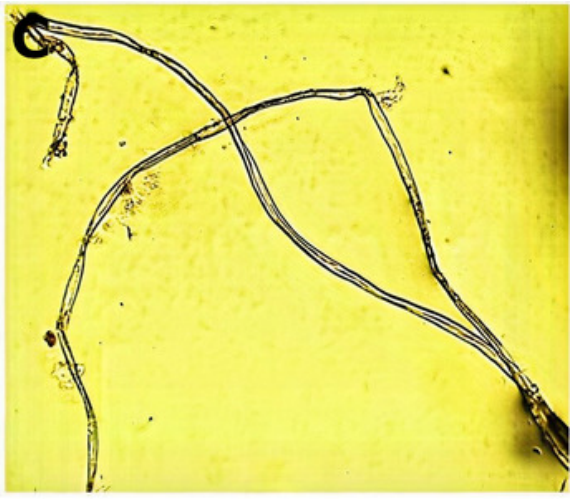

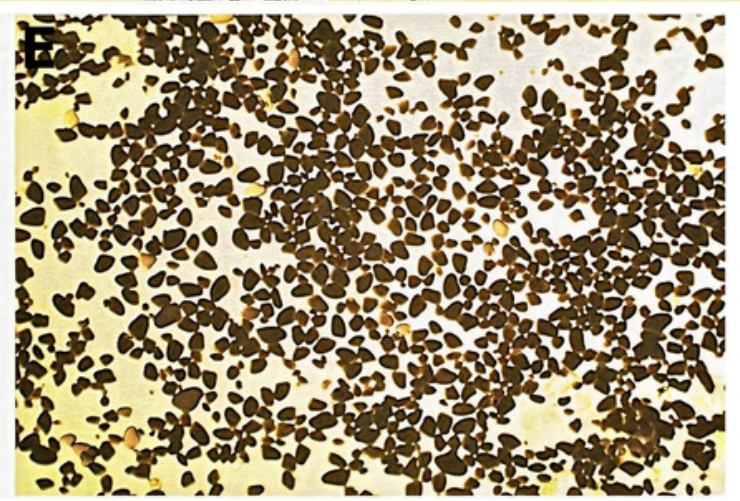




\section{Figure 3}

Phylogenetic tree of the $p s b K-p s b /$ spacer with accessions from the genus Smilax and different genera selected from the blastn results.

Three species from the genus Paris was used as outgroup. Maximum Likelihood method based on Tamura 3-parameter model. Boostrap test with 1000 replicates was performed. The tree with the highest log likelihood (-1728.93) is shown. The percentage of trees in which the associated taxa clustered together is shown next to the branches. Initial tree(s) for the heuristic search were obtained automatically by applying Neighbor-Join and BioNJ algorithms to a matrix of pairwise distances estimated using the Tamura 3 parameter model, and then selecting the topology with superior log likelihood value. A discrete Gamma distribution was used to model evolutionary rate differences among sites $(5$ categories $(+G$, parameter $=$ 1.6020)). The tree is drawn to scale, with branch lengths measured in the number of substitutions per site. This analysis involved 26 nucleotide sequences. There were a total of 368 positions in the final dataset. Evolutionary analyses were conducted in MEGA X (Kumar et al., 2018; Stecher et al., 2020). Blue arrows indicate Smilax purhampuy Ruiz from Ecuador. 


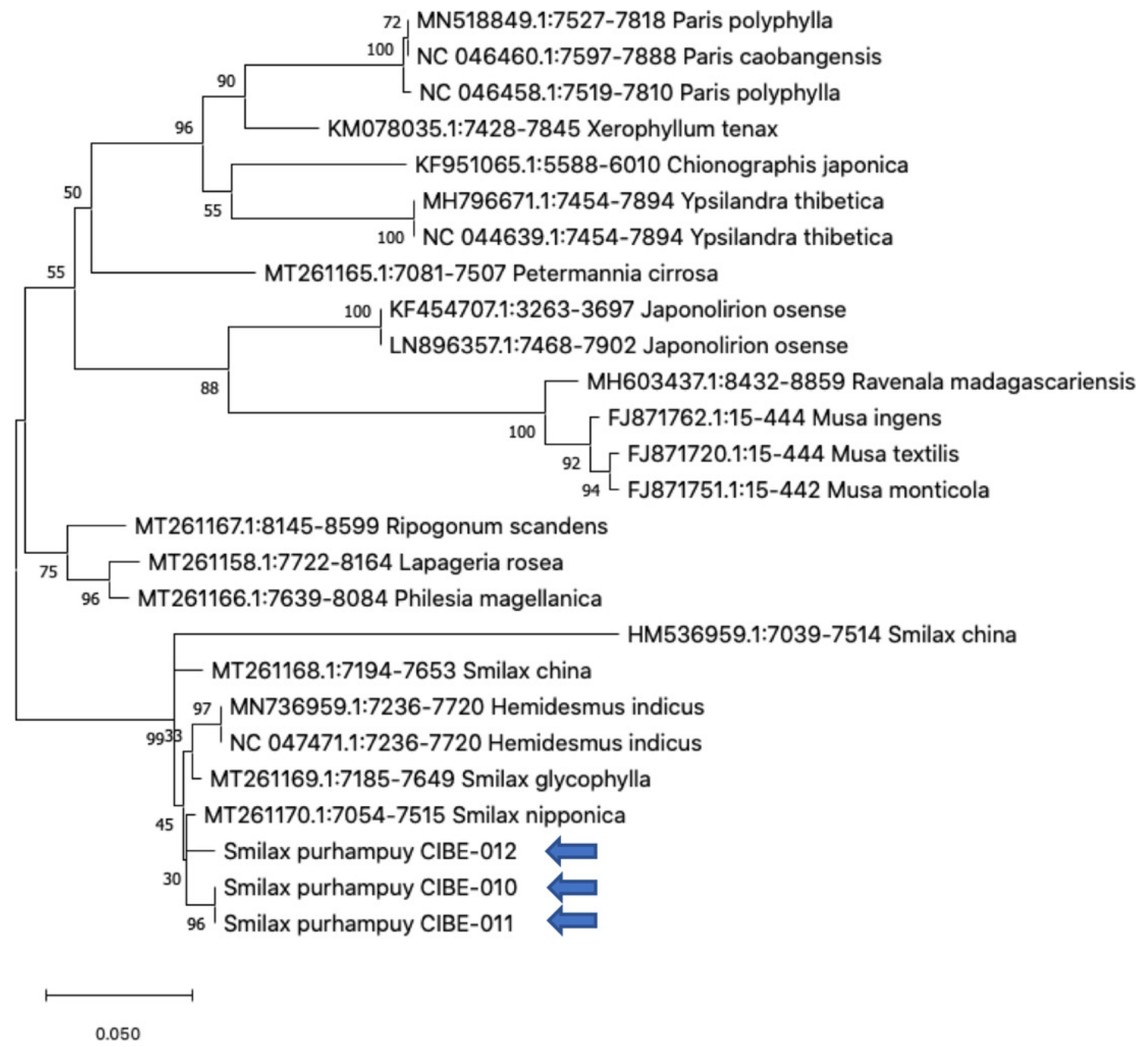




\section{Figure 4}

Phylogenetic tree of the ITS2 with accessions from the genus Smilax and different genera selected from the blastn results.

Three species from the genus Tulipa was used as outgroup. Maximum Likelihood method based on Tamura 3-parameter model. The tree with the highest log likelihood (-1405.71) is shown. The percentage of trees in which the associated taxa clustered together is shown next to the branches. Initial tree(s) for the heuristic search were obtained automatically by applying Neighbor-Join and BioNJ algorithms to a matrix of pairwise distances estimated using the Tamura 3 parameter model, and then selecting the topology with superior log likelihood value. A discrete Gamma distribution was used to model evolutionary rate differences among sites ( 5 categories $(+G$, parameter $=0.8022)$ ). The tree is drawn to scale, with branch lengths measured in the number of substitutions per site. This analysis involved 30 nucleotide sequences. There were a total of 436 positions in the final dataset.

Evolutionary analyses were conducted in MEGA X (Kumar et al. 2018; Stecher et al., 2020). Blue arrows indicate Smilax purhampuy Ruiz from Ecuador. 


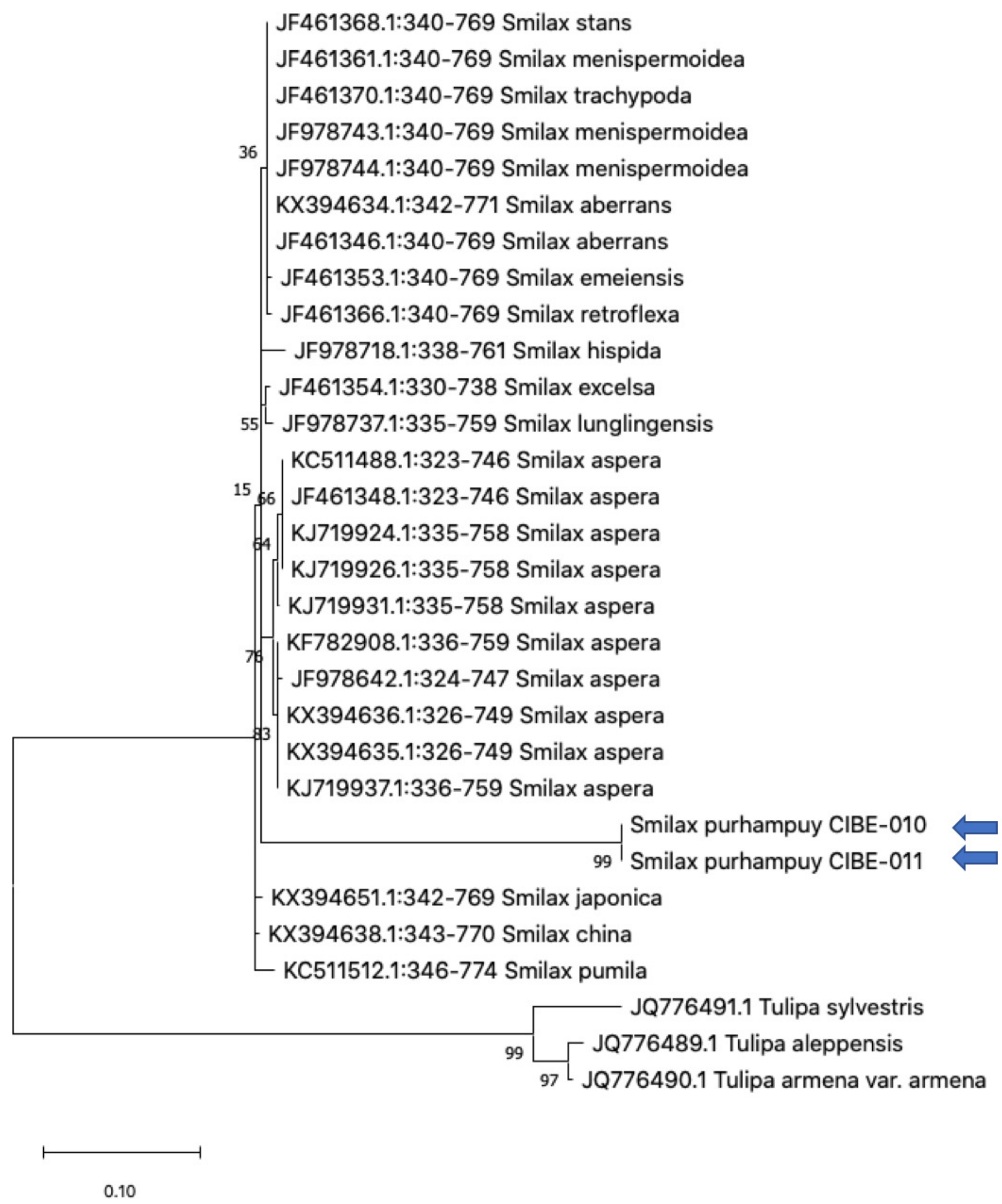

